\title{
EFEKTIVITAS BACILLUS SPP. DALAM PENURUNAN OFF-FLAVOURS PADA BUDIDAYA IKAN PATIN (PANGASIUS SP.)
}

\author{
Moh. Zharfan Abd. Djamil ${ }^{a, *}$, Heny Budi Utari ${ }^{a, b}$, Djumbuh Rukmono ${ }^{\text {b }}$ \\ aPoliteknik Ahli Usaha Perikanan, Pasar Minggu, Jakarta Selatan, Indonesia

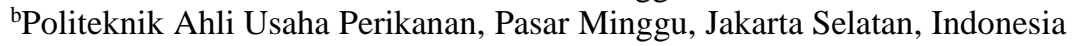 \\ *Koresponden penulis (Alamat email) : mohzharfan@yahoo.com
}

\begin{abstract}
Abstrak
Penggunaan probiotik merupakan salah satu alternatif yang dapat digunakan oleh pembudidaya ikan patin untuk meminimalisir permasalahan yang dialami pada setiap proses budidaya. Permasalahan tersebut erat kaitannya dengan mutu dan kualitas daging ikan, sehingga para pelaku usaha budidaya membutuhkan solusi terbaik untuk tetap menjaga mutu dan kualitas hasil produksi agar tetap dapat memenuhi kebutuhan ataupun permintaan pasar. Penelitian ini fokus pada upaya menurunkan bau tanah atau off-flavours melalui penggunaan probiotik Mina Pro (Bacillus spp.) yang didominasi oleh B. Licheniformis dan B. Subtilis. Pengaplikasian probiotik melalui pakan ikan dengan dosis $10 \mathrm{ml} / \mathrm{Kg}$ pakan dan $20 \mathrm{ml} / \mathrm{Kg}$ pakan. Hasil penelitian yang diperoleh kedua perlakuan lebih baik jika dibandingkan kontrol ditinjau dari beberapa parameter meliputi: Proksimat terutama pada kenaikan protein diperlakuan $10 \mathrm{ml} / \mathrm{Kg}$ pakan $(17,1 \%) ; 20$ $\mathrm{ml} / \mathrm{Kg}$ pakan (16,7\%); jika dibandingkan kontrol yang lebih rendah (14\%). Komposisi bakteri organ lambung dan usus pada perlakuan $10 \mathrm{ml} / \mathrm{Kg}$ dan $20 \mathrm{ml} / \mathrm{Kg}$ pakan lebih banyak jika dibandingkan dengan kontrol. Hasil histopatologi organ perlakun $10 \mathrm{ml} / \mathrm{Kg}$ dan $20 \mathrm{ml} / \mathrm{Kg}$ pakan lebih baik. Karena banyak terbentuk villi yang mempermudah penyerapan nutrisi pakan. Organoleptik dari daging ikan patin (punngung, ekor dan perut yang diduga muddy) pada perlakuan $20 \mathrm{ml} / \mathrm{Kg}$ pakan lebih renah. $10 \mathrm{ml} / \mathrm{Kg}$ dan $20 \mathrm{ml} / \mathrm{Kg}$ pakan memiliki nilai lebih rendah (0,2 atau masih dalam kategori sedikit muddy/kurang muddy. jika dibandingkan dengan kontrol (0,3 atau dalam kategori muddy sedang).
\end{abstract}

Kata kunci: Bacillus spp., Off-flavours, Patin

\begin{abstract}
The use of probiotics is an alternative that can be used by iridescent shark cultivators to minimize the problems experienced in each cultivation process. These problems are closely related to the quality and quality of fish meat, so that cultivators need the best solution to maintain the quality and production quality so that they can meet market needs or demands. This study focused on the efforts to decrease odor or off-flavors through the use of Mina Pro (Bacillus spp.) probiotic which is dominated by B. licheniformis and B. subtilis. The application of probiotics through fish feed at a dose of $10 \mathrm{ml} / \mathrm{Kg}$ of feed and $20 \mathrm{ml} / \mathrm{Kg}$ of feed. The results of the study obtained that both treatments were better than the control in terms of several parameters including: Proximate especially in the increase of protein treated with $10 \mathrm{ml} / \mathrm{Kg}$ of feed $(17.1 \%) ; 20 \mathrm{ml} / \mathrm{Kg}$ of feed (16.7\%); when compared to lower control (14\%). The bacterial composition of the stomach and intestines in the treatment of $10 \mathrm{ml} / \mathrm{Kg}$ and $20 \mathrm{ml} / \mathrm{Kg}$ of feed was higher than the control. The histopathological results of the $10 \mathrm{ml} / \mathrm{Kg}$ and $20 \mathrm{ml} / \mathrm{Kg}$ treated organs were better. Because many villi were formed which facilitated the absorption of feed nutrients. Organoleptic of iridescent shark meat (back, tail and belly allegedly muddy) in the treatment of $20 \mathrm{ml} / \mathrm{Kg}$ of the feed was lower. $10 \mathrm{ml} / \mathrm{Kg}$ and $20 \mathrm{ml} / \mathrm{Kg}$ of feed had lower values $(0.2$ or still in the slightly muddy/less muddy category when compared to the control $(0.3$ or in the medium muddy category).
\end{abstract}

Keywords: Bacillus spp., Off-flavors, Iridescent Shark

\section{PENDAHULUAN}

Bau tanah yang dikenal dengan istilah offflavours merupakan salah satu masalah yang sangat serius terhadap ikan-ikan air tawar yang dibudidayakan secara komersial [45]. Offflavours pada perairaran dikaitkan dengan keberadaan Geosmin (GSM) dan Dua Methylisoborneol (2-MIB) yang diakibatkan oleh akumulasi bahan organik yang berlimpah 
[55]; [41] yang menyebabkan terjadinya over populasi plankton atau Blooming algae [58]. Blooming algae sering terjadi di musim kemarau karena faktor lingkungan perairan yang mengalami peningkatan suhu, nutrien karena sisa pemberian pakan, pemupukan, fases dan bahan organik lain dalam airakibat kurangnya pergantian air [21].

GSM dan 2-MIB dalam air dapat diproduksi sekitar $0,03 \mathrm{mg} / 10^{4}$ sel oleh beberapa plankton dari golongan Cyanobacteria [15] dan akan meningkat seiring dengan bertambahnya jumlah plankton penghasil senyawa kimia tersebut. Kandungan GSM dan 2-MIB pada ikan air tawar lebih besar tersimpan pada jaringan lemak yang dapat dirasakan melalui daging ikan [7], disebabkan lebih mudah larut dalam lemak dibandingkan air. Upaya pencegahan yang lebih aman dan tidak menyebabkan stress pada ikan adalah pengaplikasian probiotik selama pemeliharaan. Cara ini membantu memperbaiki kualitas air ataupun menurunkan rasa tidak enak/apak pada daging ikan [41]; [54].

Penggunaan probiotik dapat dilakukan langsung ke air ataupun melalui pakan. Penggunaan pada media kulturdapat mempengaruhi kandungan nutrien Carbon, Nitrogen, Phospat, Kalium, yang digunakan mikroorganisme untuk pertumbuhannya. Penggunaan probiotik melalui pakan menurut Septiarini [49]; [42] dapat dikelompokkan menjadi tiga, yaitu dapat menekan populasi mikroba patogen dengan memproduksi senyawa-senyawa antimikroba melalui kompetisi nutrisi, merubah metabolisme mikrobial dengan meningkatkan atau menurunkan aktifitas enzim pengurai (selulase, protease, amilase dan lain sebagainya) dan menstimulasi imunitas.

Menurut Noviana [37] pencampuran probiotik kedalam pakan akan lebih segar dibandingkan tanpa pencampuran, karenaadanya bau atraktan dan cita rasa pada pakan yang terfermentasikan oleh probiotik sehingga merangsang ikan. Beberapa probiotik yang telah diproduksi secara komersil sebagai alternatif untuk memperbaiki kualits air dan meningkatkan pertumbuhan ikan telah banyak digunakan pada proses budidaya [2]; [25] dari golongan Bacillus spp.seperti B. Licheniformis yang dapat menstabilkan dan merangsang pertumbuhan serta B. Subtilis, B. polymyxa, B. Megaterium dan $B$. Laterosporus yang dapat menghambat pertumbuhan bakteri merugikan/patogen dan merombak organik menjadi anorganik.

Bacillus spp. memiliki kemampuan yang sangat baik, karena diduga mampu berkompetensi secara efisisen dengan bakteri merugikan dalam bioremediasi lingkungan [39]. Bakteri jenis B. Licheniformis dapat menghasilkan enzim yang dapat mengubah senyawa kompleks dari protein pakan menjadi asam amino yang lebih sederhana dan membuat daya cerna protein pada ikan lebih baik [33]; [6], serta meningkatkan kesehatan saluran pencernaan pada ikan danmenstimulasi sistem imun. B.Subtilisdapat menghasilkan spora sehingga dapat resistenpada panas dan bersifat anaerob. Sebagian besar digolongkan dalam kelas bakteri yang mampu mendegradasi senyawa organik, berperan dalam nitrifikasi dan dentrifikasi, serta dapat mengikat nitrogen [20]; [10]. Bakteri ini juga mampu memproduksi senyawa bakteriosin dan memiliki efek antagonis terhadap bakteri gram negatif dan positif [5].

Penelitian Bacillus spp. terhadap penurunan off-flavours pada budidaya ikan seperti ikan lele, nila dan salmon telah dilakukan. Tetapi belum memberikan hasil yang maksimal atau solusi terbaik untuk menurunkan off-flavours. Dalam penelitian ini dilakukan percobaan pada pengaplikasian probiotik Bacillus spp. melalui pakan dengan dosis probiotik $10 \mathrm{ml} / \mathrm{Kg}$ pakan dan $20 \mathrm{ml} / \mathrm{Kg}$ pakan. Hasil yang diharapkan yaitu secara tidak langsung dapat mengurangi senyawa GSM dan 2-MIB dalam tubuh/saluran pencernaan ikan dan dapat berkompetisi dengan produsen GSM dan 2-MIB dalam perairan.

\section{METODE PENELITIAN Waktu dan Tempat Penelitian}

Penelitian dilakukan selama 60 hari diCV. Tirto Bumi Agung (TBA), Desa karangdagangan, Kecamatan Bandarkedung mulyo, Kabupaten Jombang, Provinsi Jawa Timur, milik Ilham Subekti yang bekerjasama 
dengan PT. Central Proteina Prima. Lahan budidaya \pm 4 hektar terdiri dari 197 petak/kolam ikan, terbagi antara kolam ikan patin dan lele. Pengujian sampel ikandilakukan di laboratorium Animal Health Service PT. Central Proteina Prima (CP. PrimaSidoardjo).

\section{Alat dan Bahan Penelitian}

Alat yang digunakan meliputi 9 kolam ikan dengan luasan $400 \mathrm{~m}^{2}$, pengujian proksimat dan hematologi dilakukan di Universitas Airlangga, pengujian patologi dan histopatologi (Sakura Tissue-Tek ${ }^{\circledR}$ VIP $^{\mathrm{TM}} 5 \mathrm{Jr}$. "Japan"), pengujian bakteri organ dan bakteri air dilakukan dilaboratorium Animal Health Service PT. Central Proteina Prima, Sidoarjo. Bahan yang digunakan yaitu ikan patin dari CV. TBA, pakan ikan dari CP. Prima dan probiotik Mina Pro jenis Bacillus spp. dari PT. Marindo Lab. Pratama, Cikande, Serang.

\section{Rancangan dan Tahapan Penelitian}

Metode penelitian menggunakan Rancangan Acak Lengkap (RAL) dengan 2 perlakuan (dosis probiotik $10 \mathrm{ml} / \mathrm{Kg}$ pakan ikan, $20 \mathrm{ml} / \mathrm{Kg}$ pakan ikan, kontrol) dan masing-masing terdiri 3 ulangan. Jumlah kolam yang digunakan terdiri 9 kolam. Luas kolam yang digunakan $400 \mathrm{~m} 2$, kedalaman air \pm 2 meter, padat tebar $20 \mathrm{ekor} / \mathrm{m} 2$ dan ukuran ikan 400 g/ekor. Probiotik diaplikasikan 2 kali/minggu, probiotik diencerkan terlebih dahulu dengan $200 \mathrm{ml}$ air tawar per $\mathrm{kg}$ pakan, pencampuran probiotik dengan menyemprotkan probiotik secara merata pada pakan, selanjutnya dilakukan pengadukan pakan agar komponen probiotik terserap kedalam pori-pori pakan dan didiamkan selama 60 menit di tempat yang teduh dengan tujuan agar pakan dapat terfermentasikan, selanjutnya dilakukan pemberian pakan.

\section{Pengumpulan dan Pengolahan Data}

Pengambilan sampel ikan secara acak melalui sampling dengan interval waktu 21 hari. Pengambilan sampel ikan selanjutnya dilakukan pengujian meliputi:
a. Pengujian Proksimat;
b. Pengujjian Hematologi;
c. Pengujian Bakteri Air;
d. Penguian Bakteri Organ;
e. Pengujian Patologi;
f. Pengujian Histopatologi; dan
g. Pengujian Organoleptik (Muddy taste)

\section{Pengujian Proksimat}

Pengujian proksimat daging ikan yang diuji adalah protein, lemak, kadar abu dan kadar air berdasarkan SNI [61] dan metode yang dikembangkan Sudarmadji [51].

\section{Pengujian Hematologi}

Pengujian darah ikan patin menggunkan alat hematologi Analyzer yang dikembangkan Bastian et al., (2001) meliputi: nilai Hematokrit, Total Eritrosit/RBC, Trombosit, Hemoglobin ( $\mathrm{Hb})$, Total Leukosit/WBC, Granulosit, Limfosit dan Monosit di Laboratorium Patologi Klinik Universitas Airlangga.

\section{Pengujian Bakteri Air}

Pengujian Bakteri Air meliputi Total Bacteria Count (TBC) dan Total Aeromonas Count (TAC) melalui beberapa tahap sesuai dengan Standar Operasional Prosedur (SOP) di laboratorium Animal Health Service PT. Central Proteina Prima seperti terdapat pada Lampiran 1.

\section{Pengujian Bakteri Organ}

Pengambilan sampel organ melalui pembedahan ikan dengan mengeluarkan saluran pencernaan (lambung dan usus) dari ikan patin dewasa, selanjutnya lambung dan usus digerus, sampel ditimbang $1 \mathrm{~g}$, ditambahkan $9 \mathrm{ml}$ cairan fisiologis $(\mathrm{NaCl}$ 0,85\%) steril [28] lalu dihomogenkan dengan vortex. Proses inokulum diambil $1 \mathrm{ml}$ dan diencerkan dalam tabung pengenceran serial berisi $9 \mathrm{ml}$ larutan fisiologis, sebanyak 8 tabung pengencer. Setelah dihomogenkan, setiap tabung pengencer diambil larutan sebanyak $0,1 \mathrm{ml}$ dan disebarkan dalam cawan 
petri berisi TSA. Diinkubasi pada suhu $30^{\circ}$ Cselama 24 jam sampai koloni bakteri tumbuh [28]. Pengujian bakteri organ dilakukan di Laboratorium Animal Health Service PT. Central Proteina Prima.

\section{Pengujian Patologi}

Pengujian Patologi dilakukan pada organ ikan yaitu (lambung dan usus ikan) organ ikan difillet kemudian dilakukan pengamatan dan menghitung (\%) komposisi pada organ ikan yang dinyatakan muddy taste dan tidak muddy taste. Kriteria pengujian patologi terdapat pada Lampiran 2.

\section{Pengujian Histopatologi}

Pengujian Histopatologi menggunakan alat (Sakura Tissue-Tek ${ }^{\circledR}$ VIP ${ }^{\mathrm{TM}} 5$ Jr. "Japan”), dilakukan melalui beberapa tahap sesuai dengan Standar Operasional Prosedur (SOP) Laboratorium Animal Health Service PT. Central Proteina Prima, meliputi: pengambilan sampel organ ikan, fiksasi, preparasi, prosesing, embedding, pemotongan irisan tipis, pewarnaan, pemeriksaan dan analisa mikroskopis.

\section{Pengujian Organoleptik (Muddy taste)}

Pengujian organoleptik dilakukan untuk mengetahui bau/rasa daging ikan patin menggunakan panelis sesuai SNI 01-23462006 pada tingkat kepercayaan 95\%. Organoleptik (rasa) ditentukan oleh 3 bagian ikan (punggung, perut dan ekor) yang sering ditemukan adanya indikasi bau tanah pada daging ikan patin. Pengujian dilakukan oleh 6 orang panelis menggunakan skoring terdapat pada Lampiran 3.

\section{Analisis Data}

Hasil pengujian pada setiap parameter, selanjutnya diuji statistik (normalitas dan homogenitas data) sebagai syarat uji Anovadan apabila hasil yang diperoleh signifikan maka diteruskan dengan uji lanjut (duncan) untuk mengetahui adanya perbedaan perlakuan probiotik yang diaplikasikan terhadap penurunan off-flavours pada budidaya ikan patin.

\section{HASIL DAN PEMBAHASAN}

\section{Pengujian Proksimat}

Hasil rata-rata pengujian proksimat daging ikan patin selama penelitian setelah perlakuan ditampilkan pada Gambar 1. dan Tabel 1. 


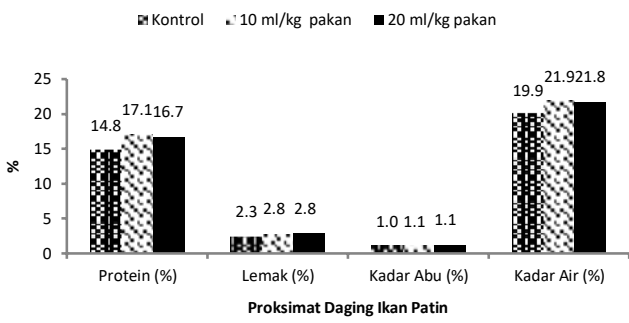

Gambar 1. Hasil rata-rata pengujian proksimat pada daging ikan setelah perlakuan selama penelitian.

Tabel 1. Hasil rata-rata pengujian proksimat daging ikan patin sebelum dan sesudah perlakuan.

\begin{tabular}{|c|c|c|c|c|c|c|}
\hline \multirow[b]{2}{*}{$\begin{array}{c}\text { Proksi } \\
\text { mat }\end{array}$} & \multirow{2}{*}{$\begin{array}{c}\text { Hasil } \\
\text { Rata-rata } \\
\text { Sebelum } \\
\text { Perlakuan }\end{array}$} & \multicolumn{3}{|c|}{ Rata-rata Sesudah Perlakuan } & \multicolumn{2}{|c|}{ Diff. $\left.(\%)^{*}\right)$} \\
\hline & & Kontrol & $\begin{array}{c}10 \\
\mathrm{ml} / \mathrm{Kg} \\
\text { pakan }\end{array}$ & $\begin{array}{c}20 \\
\mathrm{ml} / \mathrm{Kg} \\
\text { pakan }\end{array}$ & $\begin{array}{c}10 \\
\mathrm{ml} / \mathrm{Kg} \\
\text { pakan }\end{array}$ & $\begin{array}{c}20 \\
\mathrm{ml} / \mathrm{Kg} \\
\text { pakan }\end{array}$ \\
\hline $\begin{array}{l}\text { Protein } \\
(\%)\end{array}$ & 14.8 & 14.8 & 17.1 & 16.7 & $16 \%$ & $13 \%$ \\
\hline $\begin{array}{l}\text { Lemak } \\
(\%)\end{array}$ & 2.3 & 2.3 & 2.8 & 2.8 & $22 \%$ & $22 \%$ \\
\hline $\begin{array}{l}\text { Kadar } \\
\text { Abu } \\
(\%)\end{array}$ & 1.0 & 1.0 & 1.1 & 1.1 & $10 \%$ & $10 \%$ \\
\hline $\begin{array}{l}\text { Kadar } \\
\text { Air (\%) }\end{array}$ & 19.9 & 19.9 & 21.9 & 21.8 & $10 \%$ & $10 \%$ \\
\hline
\end{tabular}

Hasil pengujian proksimat selama penelitian pada pengaplikasian probiotik melalui pakan diperoleh nilai rata-rata pada komposisi kadar abu (kontrol 1,0\%; $10 \mathrm{ml} / \mathrm{Kg}$ pakan $1,1 \%$; dan $20 \mathrm{ml} / \mathrm{Kg}$ pakan $1,1 \%$ ) dan kadar air pada daging ikan (kontrol 19,9\%; 10 $\mathrm{ml} / \mathrm{Kg}$ pakan $21,9 \%$; dan $20 \mathrm{ml} / \mathrm{Kg}$ pakan $21,8 \%$ ). Kandungan kadar air yang diperoleh masih tergolong rendah sehingga tekstur daging yang dihasilkan juga lebih kenyal. Kandungan kadar air ikan patin berkisar antara $75,53-79,42 \%$ dan kadar air yang tinggi sangat mempengaruhi tekstur daging ikan menjadi lembek [52].

Probiotik dapat mempengaruhi nutrisi daging ikan patin seperti kadar protein, pada perlakuan $10 \mathrm{ml} / \mathrm{Kg}$ pakan $(17,1 \%), 20 \mathrm{ml} / \mathrm{Kg}$ pakan $(16,7 \%)$ yang lebih tinggi jika dibandingkan dengan kontrol (14,8\%), demikian pula dengan kadar lemak menghasilkan nilai rata-rata yang lebih tinggi pada perlakuan $10 \mathrm{ml} / \mathrm{Kg}$ pakan dan $20 \mathrm{ml} / \mathrm{Kg}$ pakan sebesar $2,8 \%$, sedangkan pada kontrol relatif lebih rendah sebesar 2,3\%. Penjelasan tentang kadar protein dan lemak pada ikan air tawar yaitu ikan air tawar mengandung sekitar $19 \%$ protein atau lebih sesuai komposisiprotein atau lemak pada pakan. Kandunganprotein ini bervariasi hingga $20 \%$, tergantung pada spesies dan musim dalam budidaya. Ikan juga mengandung kandungan lemak yang jauhlebih rendah jika dibandingkan dengan dagingmerah [35]. Kualitas nutrisi daging ikan secara organoleptik dapat dipengaruhi oleh degradasi lingkungan dan pakan yang diberikan selama budidaya, terutama dalam sistem budidaya semi intensif dan intensif [16]; [17].

Penyebab tingginya kandungan protein pada perlakuan $10 \mathrm{ml} / \mathrm{Kg}$ pakan $(17,1 \%)$ dan $20 \mathrm{ml} / \mathrm{Kg}$ pakan $(16,7 \%)$ jika dibandingkan dengan kontrol yang relatif lebih rendah 14,8\% karena beberapa peran dari Bacillus spp. yang dapat menghasilkan enzim untuk membantu proses pencernaan protein pakan menjadi asam amino sehingga mempermudah ikan untuk penyerapan nutrisinya. Bacillus spp. juga mempunyai sifat fisiologis yaitu memiliki kemampuan mendegradasi organik seperti protein, pati, selulosa, hidrokarbon dan agar, menghasilkan antibiotik, serta berperan dalam nitrifikasi dan dentrifikasi [36]; [8]; [32].

Beberapa penelitian ditemukan bahwa penambahan $B$. Subtilis mampu mencerna pakan dengan baik [13], sedangkan $B$. Licheniformis merupakan spesies bakteri yang mampu menghasilkan protease dalam jumlah yang relative tinggi. Menurut Phumee [43] peningkatan protein pakan berpengaruh pada kandungan protein daging ikan patin yang berdampak terhadap peningkatan retensi protein. Perlakuaan $10 \mathrm{ml} / \mathrm{Kg}$ pakan dan 20 $\mathrm{ml} / \mathrm{Kg}$ pakan menunjukan kandungan protein daging ikan patin lebih tinggi, hal tersebut didukung oleh protein pakan yang termanfaatkan dengan baik untuk sintesa protein tubuh dengan bantuan Bacillus spp.

Sintesa protein pada tubuh ikan dipengaruhi oleh lemak. Karena apabila metabolisme asam amino yang tidak termanfaatkan dengan baik untuk sintesis protein maka akan meningkatkan penimbunan 
lemak dalam tubuh ikan dan akan menyebabkan simpanan protein dalam tubuh ikan lebih rendah yang selanjutnya dapat menurunkan laju pertumbuhan dan penambahan bobot tubuh ikan [62]; [31]. Pada komposisi lemak dari perlakuan $10 \mathrm{ml} / \mathrm{Kg}$ pakan dan $20 \mathrm{ml} / \mathrm{Kg}$ pakan lebih tinggi jika dibandingkan dengan kontrol, namun masih termasuk dalam kondisi lemak rendah.Menurut Thammapat [52] bahwa kandungan lemak daging ikan patin secara umum terdiri atas lemak rendah (2-4\%), lemak sedang (4-8\%) dan lemak tinggi (>8\%). Mekanisme secara umum hidrolisis enzimatik substrat peptida menurut Moran [34] terdapat pada Gambar 2.2.

Bacillus spp. penghasil enzim protease yang mengkatalisis pemecahan ikatan peptida, polipeptida dan protein dengan reaksi hidrolisis menjadi molekul-molekul yang lebih sederhana seperti peptida rantai pendek dan asam amino [33]; [40]. Reaksi hidrolisis yang serupa ditunjukkan pada Gambar 2.

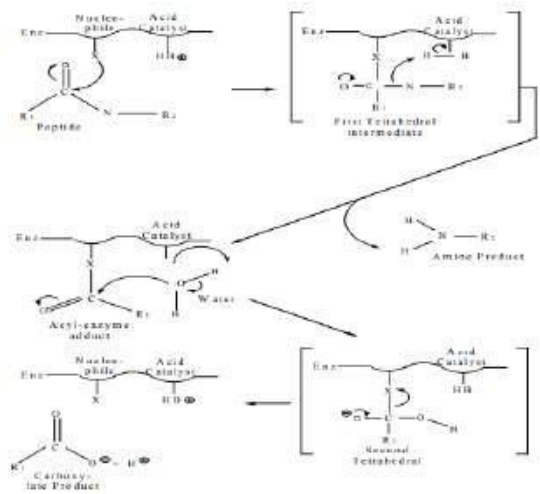

Gambar 2 Mekanisme umum hidrolisis enzimatik substrat peptida yang dapat membantu proses kecernaan pakan ikan [34].

Hidrolisis ikatan peptida adalah reaksi penambahan/penghilangan, yaitu protease bertindak sebagai nukleofilik atau bereaksi dengan membentuk satu molekul air [40]. Pada protease tertentu, adisi enzim-asil dapat dibentuk, seperti pada Gambar 2.2. intermediat tetrahedral kedua akhirnya dibentuk dan menghasilkan produk karboksilat, proton dan enzim bebas yang diregenerasi [34]. Asumsi secara umum proses kerja enzim yang dihasilkan dari Bacillus spp.melalui pencampuran pada pakan ikan patin ditampilkan pada Gambar 3.

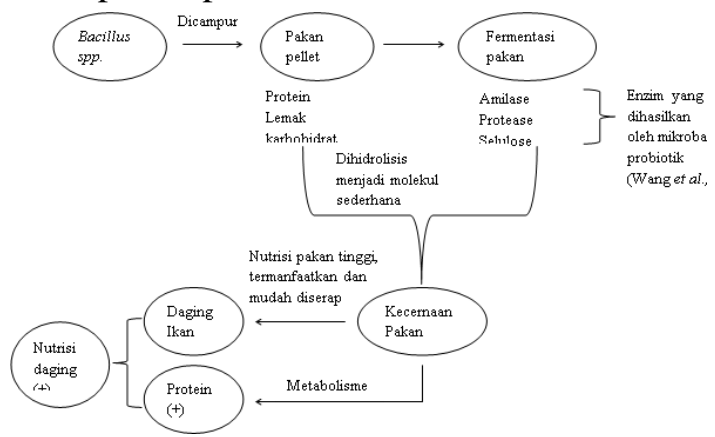

Gambar 3. Secara umum proses kerja enzim yang dihasilkan dari Bacillus spp. melalui pencampuran pada pakan ikan patin.

\section{Pengujian Hematologi}

Pengujian Hematologi sebelum dan sesudah perlakuan diperoleh hasil rata-rata yang ditampilkan pada Tabel 2 ..

Tabel 2 Hasil Rata-rata Pengujian Hematologi

\begin{tabular}{|c|c|c|c|c|}
\hline \multirow{2}{*}{$\begin{array}{l}\text { Hematologi } \\
\text { Ikan Patin }\end{array}$} & \multirow{2}{*}{$\begin{array}{l}\text { Hasil } \\
\text { Rata-rata } \\
\text { Sebelum } \\
\text { Perlakuan }\end{array}$} & \multicolumn{3}{|c|}{ Hasil Rata-rata Sesudah Perlakuan } \\
\hline & & $\cdots$ & $\begin{array}{l}10 \mathrm{ml} / \mathrm{Kg} \\
\text { pakan }\end{array}$ & $\begin{array}{c}20 \mathrm{ml} / \mathrm{Kg} \\
\text { pakan }\end{array}$ \\
\hline $\begin{array}{l}\text { Hematokrit } \\
(21-33 \%)\end{array}$ & 29 & $29 \pm 0.57^{\mathrm{ab}}$ & $32 \pm 1.52^{\mathrm{b}}$ & $28 \pm 0.33^{\mathrm{a}}$ \\
\hline $\begin{array}{l}\text { T.Eritrosit/RBC } \\
(1,0-2,5 \mathrm{x} \\
\left.10^{6} / \mathrm{mm}^{3}\right)\end{array}$ & 2.6 & $2.6 \pm 0.18^{\mathrm{a}}$ & $2.3 \pm 0.11^{\mathrm{a}}$ & $2.5 \pm 0.05^{\mathrm{a}}$ \\
\hline $\begin{array}{l}\mathrm{Hb}(5,8-8,9 \\
\mathrm{g} / \mathrm{dL})\end{array}$ & 7.3 & $7.3 \pm 0.50^{\mathrm{a}}$ & $7.0 \pm 0.06^{\mathrm{a}}$ & $7.1 \pm 0.14^{\mathrm{a}}$ \\
\hline $\begin{array}{l}\text { Trombosit } \\
(200-500 x \\
\left.10^{3} / \mathrm{mm}^{3}\right) \\
\text { T. }\end{array}$ & 298 & $298 \pm 5.56^{\mathrm{a}}$ & $317 \pm 7.54^{\mathrm{a}}$ & $329 \pm 17.5^{\mathrm{a}}$ \\
\hline $\begin{array}{l}\text { Leukosit/WBC } \\
(20,0-150,0 \mathrm{x} \\
\left.10^{3} / \mathrm{mm}^{3}\right)\end{array}$ & 41.2 & $41.2 \pm 1.63^{\mathrm{b}}$ & $41.4 \pm 1.28^{b}$ & $35.8 \pm 1.17^{\mathrm{a}}$ \\
\hline $\begin{array}{l}\text { Granulosit (3- } \\
8 \%)\end{array}$ & 8 & $8 \pm 0.88^{\mathrm{a}}$ & $6 \pm 0.33^{\mathrm{a}}$ & $7 \pm 0.33^{\mathrm{a}}$ \\
\hline $\begin{array}{l}\text { Limfosit (57- } \\
87 \%)\end{array}$ & 86 & $86 \pm 0.88^{a}$ & $88 \pm 0.57^{\mathrm{a}}$ & $87 \pm 0.88^{a}$ \\
\hline Monosit (2-5\%) & 5 & $5 \pm 0.33^{\mathrm{a}}$ & $5 \pm 0.33^{\mathrm{a}}$ & $4 \pm 1.22^{\mathrm{a}}$ \\
\hline
\end{tabular}

Hasil rata-rata pengujian hematologi diperoleh nilai darah hemaktokrit, Total Eritrosit/RBC, $\mathrm{Hb}, \quad$ Trombosit, Total Leukosit/WBC, Granulosit, Limfosit dan Monosit yang terlihat normal untuk standar hematologi ikan air tawar. Menurut Bastiawan [4] apabila ikan terserang penyakit dan nafsu makan ikan menurun dapat mempengaruhi hematokrit dan eritrosit rendah. Rata-rata nilai hematokrit dan eritrosit ikan patin perlakuan 10 $\mathrm{ml} / \mathrm{Kg}$ pakan, $20 \mathrm{ml} / \mathrm{Kg}$ pakan dan kontrol 
berada pada kisaran normal untuk standar ikan patin. Hal tersebut menunjukan pemberian probiotik melalui pakan tidak mempengaruhi nilai gambaran darah pada ikan patin.

Hasil kadar $\mathrm{Hb}$ ikan patin untuk perlakuan $10 \mathrm{ml} / \mathrm{Kg}$ pakan, $20 \mathrm{ml} / \mathrm{Kg}$ pakan dan kontrol tergolong normal. $\mathrm{Hb}$ berfungsi mengikat oksigen yang digunakan untuk proses katabolisme sehingga dihasilkan energi [29]; [4]. Kemampuan mengikat oksigen dalam darah tergantung pada jumlah $\mathrm{Hb}$ yang terdapat dalam sel darah merah. Rendahnya kadar $\mathrm{Hb}$ mempengaruhi metabolisme menurun dan

energi yang dihasilkan menjadi rendah menyebabkan ikan menjadi lemah, nafsu makan menurun, diam di dasar dan

menggantung dibawah permukaan air [4].

Hasil pengecekan trombosit perlakuan 10 $\mathrm{ml} / \mathrm{Kg}$ pakan, $20 \mathrm{ml} / \mathrm{Kg}$ pakan dan kontrol menunjukan kisaran nilai normal untuk jenis ikan air tawar Jumlah leukosit ikan patin perlakuan perlakuan $10 \mathrm{ml} / \mathrm{Kg}$ pakan, $20 \mathrm{ml} / \mathrm{Kg}$ pakan dan kontrol diperoleh kisaran nilai normal (Tabel 2.). Meningkatnya produksi jumlah sel darah putih ikan menunjukkan adanya respon perlawanan tubuh terhadap zat asing penyebab penyakit. Leukosit ikan patin terdiri dari monosit, limfosit, dan neutrofil (agranulosit). Menurut Bastiawan [4] monosit berfungsi sebagai fagosit terhadap benda-benda asing yang berperan sebagai agen penyakit. Limfosit berfungsi sebagai penghasil antibodi untuk kekebalan tubuh dari gangguan penyakit. Neutrofil berperan dalam respon kekebalan terhadap serangan organisme patogen dan mempunyai sifat fagositik dan neutrofil dalam darah meningkat apabila terjadi infeksi yang berperan sebagai pertahanan pertama tubuh ikan [9]. Nilai rata-rata leukosit pada perlakuan $20 \mathrm{ml} / \mathrm{Kg}$ pakan relatif lebih rendah diduga adanya penurunan terhadap infeksi yang terjadi pada ikan patin.

\section{Total Bakteri Air}

Hasil rata-rata pengecekan Total Bakteri Air (Total Bacteria Count atau TBC) dalam $10^{3} \mathrm{CFU} / \mathrm{ml}$ selama penelitian ditampilkan

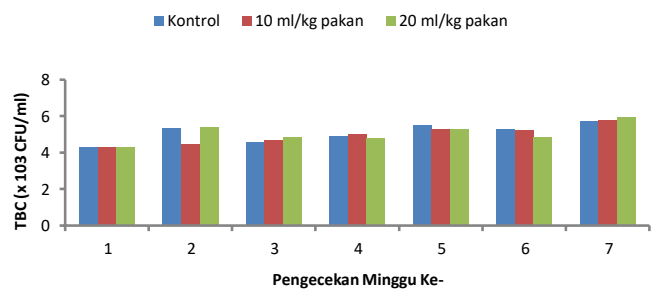

Gambar 4.Hasil rata-rata TBC air selama penelitian

Tabel 3. Hasil rata-rata TBC air sebelum dan sesudah perlakuan pemberian probiotik Bacillus spp.

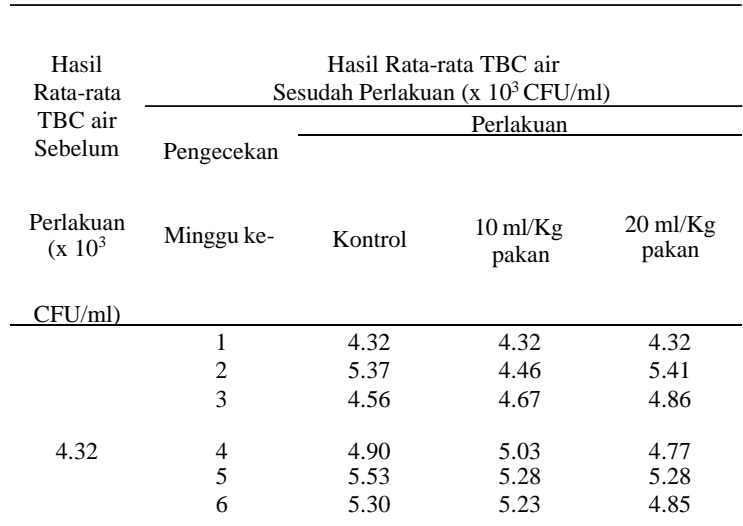

pada Gambar 4. dan Tabel 3. 
Hasil pengecekan rata-rata TBC air dari penelitian ini diperoleh pada kontrol sedikit lebih tinggi $\left(5,10 \times 10^{3}\right.$ $\mathrm{CFU} / \mathrm{ml})$, dibandingkan perlakuan 10 $\mathrm{ml} / \mathrm{Kg}$ pakan $\left(5,03 \times 10^{3} \mathrm{CFU} / \mathrm{ml}\right)$ dan $20 \mathrm{ml} / \mathrm{Kg}$ pakan $\left(4,94 \times 10^{3} \mathrm{CFU} / \mathrm{ml}\right)$. Nilairata-rata bakteri air baik kontrol maupun perlakuan masih dalam kisaran yang baik untuk budidaya ikan patin yaitu $1,0 \times 10^{2}$ sampai $8,7 \times 10^{5} \mathrm{CFU} / \mathrm{ml}$ (Jun et al., 2000). Sedangkan hasil penelitian Harbi dan Udin (2010) untuk total bakteri air pada ikan catfishsedikit lebih rendah yaitu $7,9 \pm 4.4 \times 10^{3}$ to 4,3 $\pm 5,7 \times 10^{4}$.

\section{Pengujian Bakteri Organ}

Hasil rata-rata pengujian bakteri organ lambung dan usus pada ikan patin (x $\left.10^{8} \mathrm{CFU} / \mathrm{ml}\right)$. Pengujian bakteri tersebut meliputi Total Bakteri atau Total Bacteria Count (TBC) dan Total Aeromonas atau Total Aeromonas Count (TAC) ditampilkan pada Gambar 5 dan Tabel 4. 


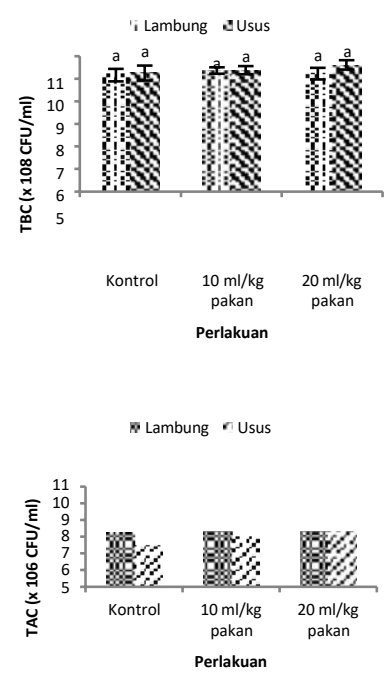

Gambar 5. Hasil rata-rata pengujian TBC dan TAC pada organ ikan patin selama penelitian sebelum dan sesudah perlakuan.

Tabel 4. Hasil Rata-rata Pengujian Bakteri Organ (x $\left.10^{8} \mathrm{CFU} / \mathrm{ml}\right)$

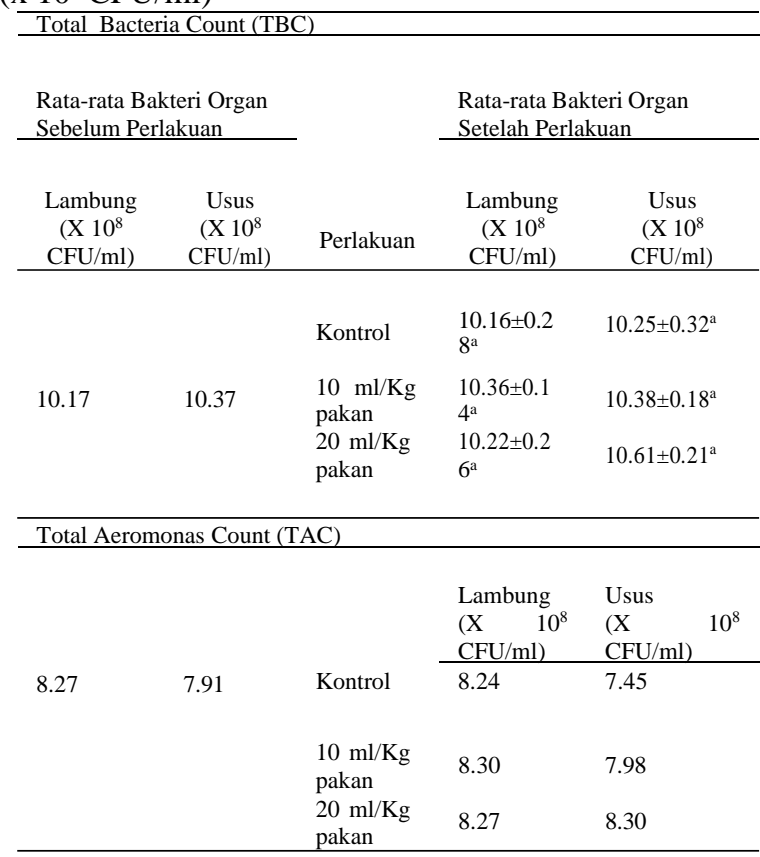

Hasil rata-rata pengecekan TBC organ ikan patin pada organ lambung perlakuan 10 $\mathrm{ml} / \mathrm{Kg}$ pakan memiliki jumlah koloni TBC lebih tinggi $\left(10,36 \times 10^{8}\right)$, perlakuan $20 \mathrm{ml} / \mathrm{Kg}$ pakan $\left(10,22 \times 10^{8}\right)$ dan kontrol lebih rendah $\left(10,16 \times 10^{8}\right)$. Sebaliknya pada organ usus jumlah TBC terbanyak didominasi oleh perlakuan $20 \mathrm{ml} / \mathrm{Kg}$ pakan $\left(10,61 \times 10^{8}\right)$, perlakuan $10 \mathrm{ml} / \mathrm{Kg}$ pakan $\left(10,38 \times 10^{8}\right)$ dan
Berdasarkan hasil uji Anova diperoleh nilai signifikan pada bakteri lambung dan bakteri usus tidak berbeda nyata, tetapi hasil yang diperoleh secara deskriptif menunjukan adanya perbedaan pada setiap perlakuan terhadap penurunan off-flavours.

Probiotik dalam budidaya ikan dapat diaplikasikan melalui pakan ataupun pada media budidaya. Menurut Kesarcodi-Watson at al., (2012) probiotik Bacillus spp.melalui pakan dapat memberikan pengaruh positif bagi kelangsungan hidup ikan patin, mempermudah proses penyerapan nutrisi pakan dan mampu memperbaiki lingkungan pada saluran pencernaan. Berdasarkan pendapat KesarcodiWatson [26] spesies Bacillus spp. merupakan mikroflora usus sehingga lebih mudah menyesuaikan diri pada lingkungan usus sebagai mikroorganiseme untuk menunjang pertumbuhan ikan, dapat menghasilkan imunostimulan dan antibiotik seperti jenis $B$. Subtilis dan B. Licheniformis [22]; [3]. Ditambahkan oleh Irianto [23].probiotik dapat
mengatur

menghalangi mikroorganisme patogen dalam usus dengan melepas enzim yang membantu proses pencernaan makanan, hal ini menyebabkan jumlah bakteri pada organ usus lebih padat seperti pada perlakuan $10 \mathrm{ml} / \mathrm{Kg}$ pakan dan $20 \mathrm{ml} / \mathrm{Kg}$ pakan. Fungsi bakteri diyakini mampu meningkatkan daya cerna pada ikan dengan bantuan Bacillus spp. yang

dan amilase [25] untuk mempermudah penyerapan nutrisi pada pakan. Proses penyerapan yang baik juga ditunjukkan dengan kontrol lebih rendah $\left(10,25 \times 10^{8}\right)$. Secara umum rata rata jumlah normal TBC pada lambung dan usus ikan air tawar berkisar antara $2,2 \times 10^{9} \mathrm{CFU} / \mathrm{ml}$ dan $2,4 \times 10^{9}$ $\mathrm{CFU} / \mathrm{ml}$

[26]. 


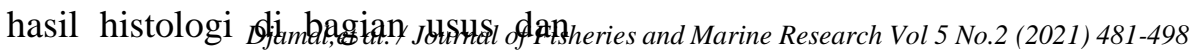
tambung terdapat banyak villi (Gambar2.8 dan 2.9)

Secara umum keberadaan bakteri pada saluran pencernaan ikan menurut Kurniasih

[28] mempunyai aktivitas enzim amolitik (mencerna karbohidrat), proteolitik (mencerna protein), dan lipolitik (mencerna lemak), dimanfaatkan untuk meningkatkan daya cerna pakan. Bacillus spp. juga berperan penting dalam proses dekomposisi bahan organik [1]; [57]. Menurut Fuller (1992) genus Bacillus spp. mampu tumbuh pada suhu lebih dari $50^{\circ} \mathrm{C}$ dan mampu menghasilkan spora. Melihat sifat yang dimiliki Bacillus spp. maka perkembangbiakan mikroba dapat dilakukan di 
luar maupun di dalam saluran pencernaan ikan yang dipergunakan untuk menekan pertumbuhan bakteri patogen.

\section{Pengujian Patologi}

Keberadaan probiotik pada saluran pencernaan ikan akan memakan sisa atau menggunakan bahan buangan dari sisa metabolisme [41]. Beberapa jenis bakteri memiliki peran penting meningkatkan pemanfaatan pakan, kesehatan ikan, dan perbaikan mutu lingkungan dan mikroorganisme [57]. Pemberian probiotik dapat meningkatkan total bakteri usus pada ikan. Hasil ini sesuai dengan total bakteri usus pada ikan yang lebih tinggi dibandingkan dengan lambung (Sari, 2014). Menurut Kesarcodi-Watson [27] spesies bakteri probiotik merupakan mikroflora normal usus sehingga bakteri tersebut lebih mudah menyesuaikan diri dengan lingkungan usus salah satu jenis Bacillus yang pernah diuji coba untuk menunjang pertumbuhan ikan, sebagai imunostimulan dan antibotik diantaranya $B$. Subtilis dan B. Licheniformis [30]. Berbagai penelitian menunjukkan bahwa Bacillus spp. yang memiliki spora dapat berkecambah dan bertahan hidup pada saluran pencernaan ikan yang berbeda, bakteri ini dianggap sebagai anaerob fakultatif dan bagian dari mikrobiota inang yang aktif secara metabolik [56]; [30]. Berikut ini perbedaan pada organ yang diidentifikasi mengalami muddy taste dan tidak muddy taste pada ikan patin ditampilkan pada Tabel 5 .

Tabel 5. Komposisi organ usus ikan patin penyebab muddy taste dan tidak muddy taste

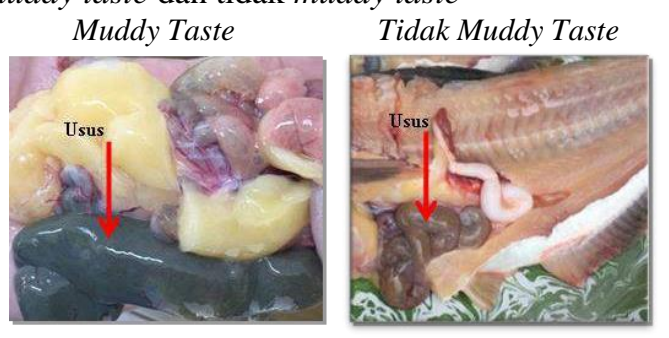

\begin{tabular}{|c|c|}
\hline $\begin{array}{l}\text { Keterangan: setelah organ } \\
\text { dibedah dan pengamatan } \\
\text { secara visual. } \\
\text { 1. } \\
\begin{array}{l}\text { Tekstur usus lebih } \\
\text { keras } \\
\text { 2. } \\
\text { 3. }\end{array} \text { Terbau tanah/lumpur } \\
\text { padat lumpur yang } \\
\text { 4. Dalam organ usus } \\
\text { berwarna hitam } \\
\text { disebabkan karena } \\
\text { akumulasi bahan } \\
\text { organik dan lumpur. } \\
\text { Organ usus cenderung } \\
\text { lebih besar/bengkak } \\
\text { disebabkan karena } \\
\text { padat. }\end{array}$ & $\begin{array}{l}\text { Keterangan: setelah } \\
\text { organ dibedah dan } \\
\text { pengamatan secara } \\
\text { visual. } \\
\text { 1. Tekstur usus lebih } \\
\text { lembek/lembut } \\
\text { 2. Berbau pakan } \\
\text { 3. Terdapat pakan } \\
\text { sepanjang organ } \\
\text { usus. } \\
\text { 4. } \begin{array}{l}\text { Dalam organ usus } \\
\text { berwarna coklat }\end{array} \\
\text { disebabkan karena } \\
\text { akumulasi pakan. } \\
\text { 5. Organ usus } \\
\text { cenderung lebih } \\
\text { kecil ataupun lunak } \\
\text { namun terisi } \\
\text { dengan pakan yang } \\
\text { padat. }\end{array}$ \\
\hline
\end{tabular}


Sesudah Perlakuan Probiotik Bacillus spp. + Pakan

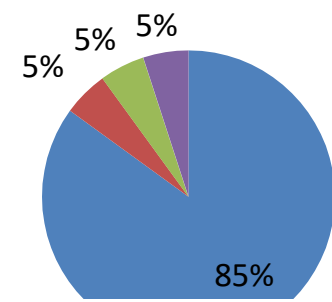

Sebelum Perlakuan

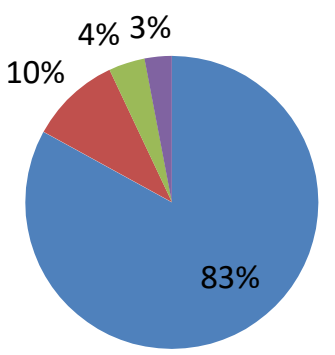

Kotoran

lumpur

- Plankton

mati

Sisa pakan

- Lain
Kontrol. Pengujian 1

$$
\begin{aligned}
& \text { Kotoran } \\
& \text { lumpur } \\
& \text { Plankton } \\
& \text { mati } \\
& \text { Sisa pakan }
\end{aligned}
$$

\section{- Lain}

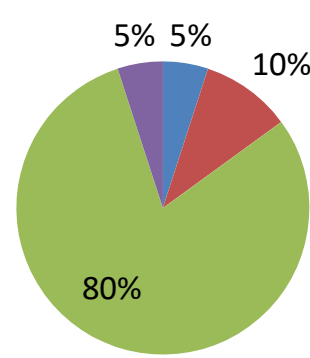

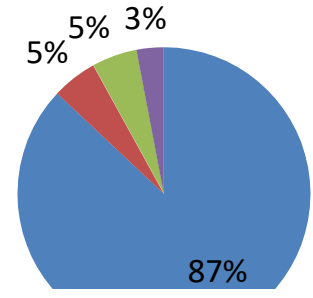

Kontrol. Pengujian 2

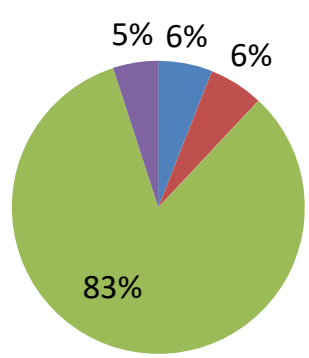

$10 \mathrm{ml} / \mathrm{Kg}$ pakan. Pengujian 2

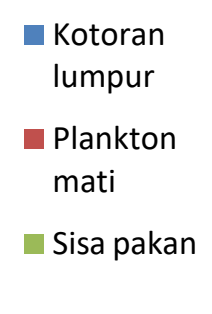

Lain

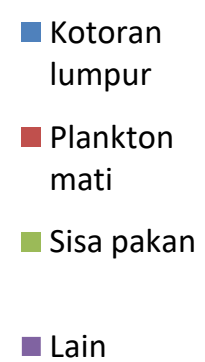

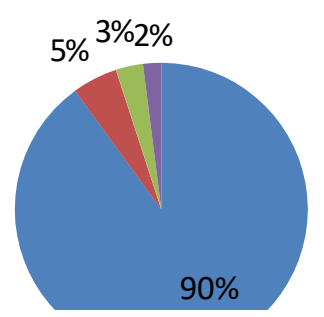

Kontrol. Pengujian 3

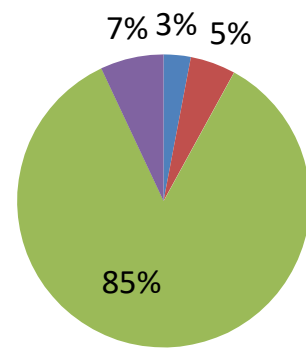

Kotoran lumpur

- Plankton

mati

Sisa pakan

Lain

Kotoran

lumpur

Plankton

mati

Sisa pakan

Lain
$10 \mathrm{ml} / \mathrm{Kg}$ pakan. Pengujian 1

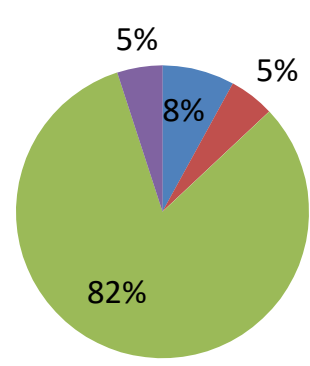

20 ml/Kg pakan Pengujian 1

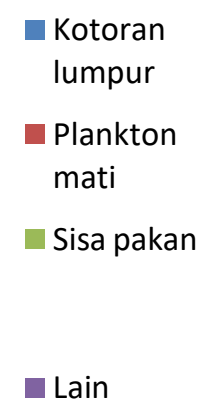

$20 \mathrm{ml} / \mathrm{Kg}$ pakan Pengujian 2
$10 \mathrm{ml} / \mathrm{Kg}$ pakan. Pengujian 3
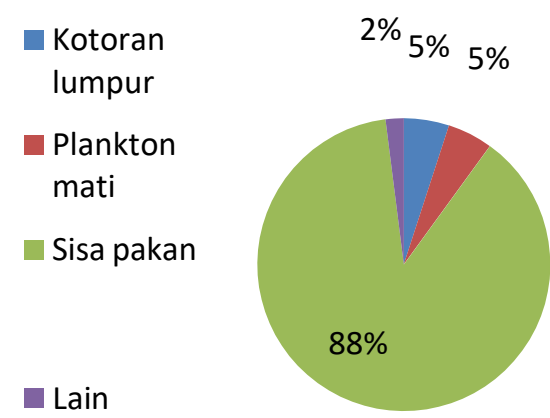

Kotoran lumpur

Plankton

mati

Sisa pakan

- Lain

Gambar 6. Hasil rata-rata komposisi organ usus yang diindikasikan muddy taste atau off-flavours pada ikan patin 


\section{Pengujian Histopatologi}

Pengujian Histopatologi pada organ ikan patin (insang, lambung dan usus) selama penelitian diperlihatkan pada Gambar 7;8 dan 9 .

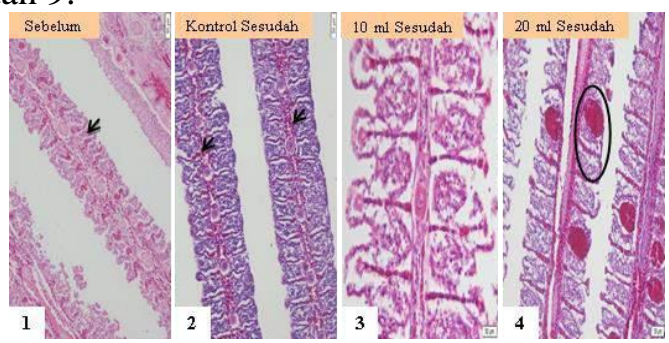

Gambar 7. Gambaran insang ikan sebelum dan sesudah perlakuan Bacillus spp. (1) Hasil pengecekan insang sebelum perlakuan, menunjukan telangiaktase (Scale bar $=50 \mu \mathrm{m}) ;(2)$ Insang pada control, menunjukan hemoragi (Scale bar = 50 $\mu \mathrm{m}$ ); (3) dan (4) Insang $10 \mathrm{ml}$ dan $20 \mathrm{ml}$ menunjukan fusi lamela sekunder dan kongesti $($ Scale bar $=50 \mu \mathrm{m})$. Secara umum kondisi ikan sebelum dan setelah perlakuan kondisi tidak berbeda secara lingkungan perairan ikan masih dalam kondisi baik.

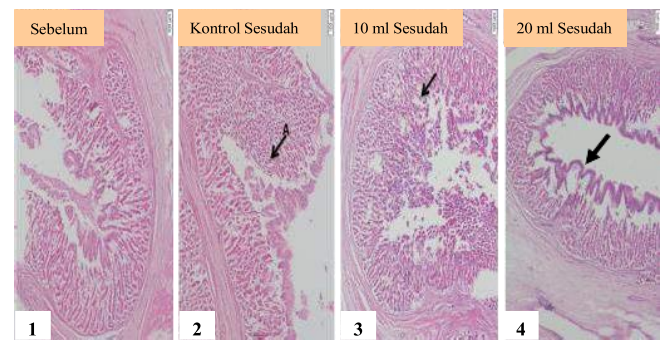

Gambar 8. Gambaran lambung ikan patin sebelum dan sesudah perlakuan probiotik Bacillus spp. (1) pengecekan Lambung sebelum perlakuan, menunjukan degenerasi hidropik (Scale bar $=50$ $\mu \mathrm{m})$; (2) Lambung pada kontrol dan (3) Lambung $10 \mathrm{ml}$,dan (4) Lambung $20 \mathrm{ml}$ setelah perlakuan masing-masing menunjukan degenerasi hidropik (panah hitam). $($ Scale bar $=50 \mu \mathrm{m})$; Namun pada perlakuan $20 \mathrm{ml}$ sudah terbentuk villi (panah besar) (Perbesaran 100 kali) (Scale bar $=50 \mu \mathrm{m})$.

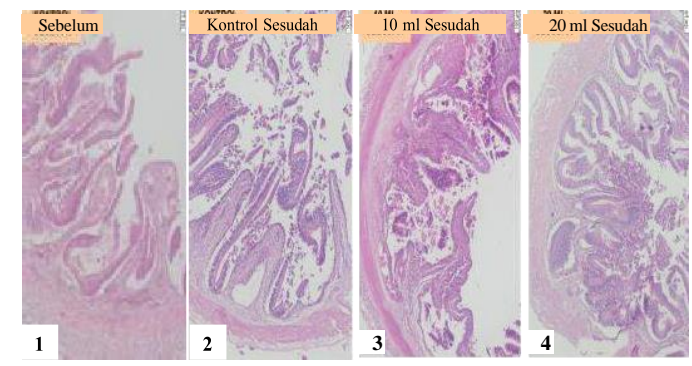

Gambar 9 Gambaran usus ikan patin sebelum dan sesudah perlakuan probiotik Bacillus spp. (1) Hasil pengecekan Usus sebelum perlakuan, menunjukan desquamasi epitel (Scale bar $=20 \mu \mathrm{m})$; (2) Usus pada control, (3) Usus $10 \mathrm{ml}$ (4) dan usus $20 \mathrm{ml}$ menunjukan desquamasi epitel, namun pada kontrol lebih parah, yang terbaik kondisinya adalah pada $20 \mathrm{ml}$ (Scale bar $=50 \mu \mathrm{m}($ Scale bar $=$ $20 \mu \mathrm{m})$.

Beberapa kelainan pada organ ikan yang ditemukan selama penelitian seperti telangiaktase merupakan adanya pelebaran pada lamela sekunder sehingga membentuk seperti raket. Selain itu lamela insang membesar dan berisikan sel darah, terjadi penimbunan sel darah merah pada lamela sekunder [46]; [47]. Hemoragi adanya pembuluh darah pecah dan darah berada pada tempat yang tidak semestinya, menunjukan bukti pendarahan pada sel karena infeksi atau sebab lainnya [35]; [44]). Fusi lamela sekunderatau menyatunya lamela sekunder insang bisa dikarenakan adanya infeksi yang disebabkan oleh bakteri seperti epystilis, trichodina, ichthyophthyrius, dactylogyrus dan gyrodactylus atau karena kondisi lingkungan yang buruk. Kongesti merupakan pendarahan pada organ, akibat pelebaran pembuluh darah dan didalam pembuluh tersebut penuh berisi darah [50]. Degenerasi hidropik terjadi karena adanya sel yang cedera sehingga tampak menjadi bengkak. Sel menjadi membesar karena akumulasi air dalam sitoplasma dan sitoplasma tampak pucat [48]. Desquamasi epithel adalah adanya sel yang terbuka/terluka atau rusak, sering terjadi pada organ lambung atau usus ikan (Ploeksic, 2010). Perubahan organ dari perlakuan $20 \mathrm{ml}$ terlihat lebih baik dibandingkan dengan $10 \mathrm{ml}$ maupun kontrol.Pada perlakuan $20 \mathrm{ml}$ ditemukan adanya fillie yang berfungsi untuk penyerapan sari-sari makanan.

Penggunaan Bacillus spp dalam penelitian ini selain menghasilkan enzim juga mampu memulihkan bakteri di usus dan menggantikan bakteri berbahaya seperti Aeromas dengan bakteri normal flora lebih baik [44]; [59]. Bacillus spp. dalam budidaya ikan dapat meningkatkan aktivitas lipase, protease dan amilase pada ikan. Sehingga mampu 
meningkatkan kinerja pertumbuhan, respons imun, ketahanan terhadap penyakit, dan kelangsungan hidup budidaya [26].

Menurut Okpokwasili dan Alapiki [38] menambahkan kelimpahan bakteri yang tinggi belum tentu merugikan, jika bakteri tidak bersifat patogen. Kelimpahan bakteri yang tinggi dapat mengindikasikan daur ulang bahan organik yang sehat dan mineralisasi ulang. Variasi jumlah bakteri di kolam ikan hampir sama dengan variasi jumlah bakteri di organ pencernaan ikan.

\section{Pengujian Organoleptik Muddy taste}

Hasil pengujian organoleptik muddy selama penelitian diperoleh nilai rata-rata dari setiap perlakuan yang dapat dilihat pada Gambar 10 dan Tabel 6.

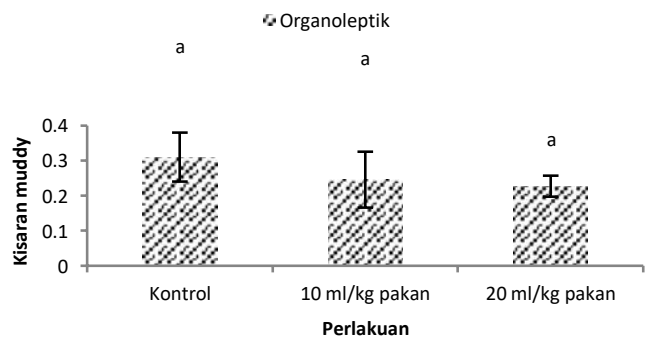

Gambar 10. Hasil rata-rata pengujian Organoleptik tiga kali (interval waktu 21 hari) selama penelitian pada daging ikan patin setelah pemberian probiotik Bacillus spp. pada pakan.

Tabel. 6. Skala rasa bau lumpur/tanah(muddy taste)

pada ikan patin

\begin{tabular}{|c|c|c|c|c|}
\hline $\begin{array}{c}\text { Skala Rasa } \\
\text { bau lumpur/ } \\
\text { tanah } \\
\text { Sesifikasi } \\
\text { sampel ikan }\end{array}$ & Nilai & $\begin{array}{l}\text { Kisaran } \\
m u d d y\end{array}$ & \multicolumn{2}{|c|}{ Hasil Penelitian } \\
\hline $\begin{array}{l}\text { Sangat } \\
\text { Muddy atau } \\
\text { Muddy } \\
\text { Tinggi }\end{array}$ & 3 & 0,50 & Perlakuan & Muddy \\
\hline $\begin{array}{l}\text { Muddy } \\
\text { Sedang } \\
\text { Sedikit }\end{array}$ & 2 & 0,33 & Kontrol & $\begin{array}{r}0,31 \pm 0 \\
.07^{\mathrm{a}}\end{array}$ \\
\hline $\begin{array}{l}\text { Muddy atau } \\
\text { Kurang } \\
\text { Muddy }\end{array}$ & 1 & 0,17 & $\begin{array}{l}10 \mathrm{ml} / \mathrm{Kg} \\
\text { pakan }\end{array}$ & $\begin{array}{r}0,24 \pm 0 \\
.08^{\mathrm{a}}\end{array}$ \\
\hline Normal & 0 & 0,00 & $\begin{array}{l}20 \mathrm{ml} / \mathrm{Kg} \\
\text { pakan }\end{array}$ & $\begin{array}{r}0,22 \pm 0 \\
.03^{\mathrm{a}} \\
\end{array}$ \\
\hline
\end{tabular}

492 mengetahui tingkat rasa pada daging ikan patin setelah penggunaan probiotik Mina Pro (Bacillus spp.) yang diaplikasikan melalui pakan apakah dapat menurunkan bau tanah pada daging ikan patin. Hasil pengecekan organoleptik dari ketiga perlakuan (kontrol, 10 $\mathrm{ml} / \mathrm{Kg}$ pakan dan $20 \mathrm{ml} / \mathrm{Kg}$ pakan) diperoleh adanya penurunan muddy pada daging ikan yang ditunjukan pada perlakuan $10 \mathrm{ml} / \mathrm{Kg}$ pakan (kisaran muddy 0,24) dan $20 \mathrm{ml} / \mathrm{Kg}$ pakan (kisaran muddy 0,22) pada skala 2 atau muddy sedang. Jika dibandingkan dengan kontrol, kedua perlakuan tersebut $(10 \mathrm{ml} / \mathrm{Kg}$ pakan dan $20 \mathrm{ml} / \mathrm{Kg}$ pakan) menunjukan adanya penurunan bau lumpur/tanah pada daging ikan patin. Perlakuan $20 \mathrm{ml} / \mathrm{Kg}$ pakan lebih baik tetapi masih tipis (slight).

Berdasarkan hasil uji statistik (Anova) diperoleh nilai pengecekan muddy ini tidak

signifikan antara kontrol, perlakuan $10 \mathrm{ml} / \mathrm{Kg}$ pakan dan $20 \mathrm{ml} / \mathrm{Kg}$ pakan. Tetapi hasil yang diperoleh selama penelitian menunjukan adanya penurunan bau lumpur/tanah yaitu pada perlakuan $20 \mathrm{ml} / \mathrm{Kg}$ pakan dan $10 \mathrm{ml} / \mathrm{Kg}$ pakan jika dibandingkan dengan kontrol. Hasil

pengecekan daging ikan patin dari pengujian muddy ditampilkan pada Gambar 11. danTabel 7.

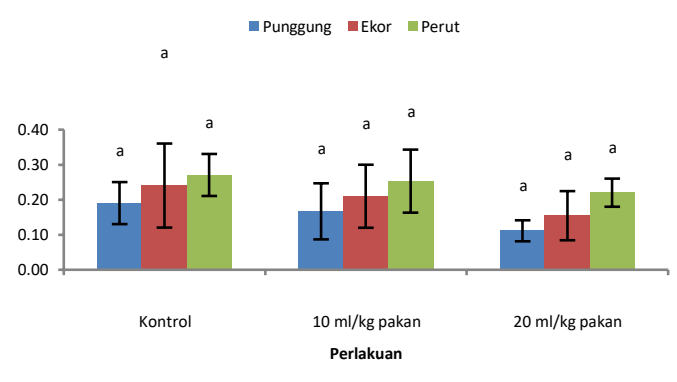

Gambar 11. Hasil rata-rata pengecekan muddy taste dari tiga area pada daging ikan patin (Punggung, Ekor dan Perut).

Tabel 7. Pengecekan muddy taste pada ikan patin (Punggung, Perut dan Ekor).

\begin{tabular}{lccc}
\hline Titik Muddy & $\begin{array}{c}\text { Perlakuan } \\
\text { Kontrol }\end{array}$ & $10 \mathrm{ml} / \mathrm{Kg}$ & $20 \mathrm{ml} / \mathrm{Kg}$ \\
& & pakan & pakan \\
\hline Punggung & $0.19 \pm 0.06^{\mathrm{a}}$ & $0.17 \pm 0.08^{\mathrm{a}}$ & $0.11 \pm 0.03^{\mathrm{a}}$ \\
\hline
\end{tabular}




Identifikasi sumber utama mikroba
penghasil GSM dan 2-MIB dapat difokuskan
pada cyanobacteria (ganggang biru-hijau).
Selain produk metabolisme mikroba, off-
flavours dapat juga berasal dari sumber lain
seperti berasal dari oksidasi lipid atau
pembusukan bakteri yang terkait dengan
penanganan dan penyimpanan pasca panen
yang tidak tepat [27]; [24]; [14] menyarankan
bahwa efisiensi dalam penggunaan pakan ikan
dan pengontrolan kualitas air terutama pada
komposisi plankton sangat diperhatikan karena
menjadi sumber GSM dan 2-MIB [9].Metabolit
sekunder penyebab off-flavours merupakan zat
dan cyanotoxin yang diproduksi oleh sel
cyanobacteria selama fase eksponensial
pertumbuhan, dan kemudian dialihkan ke
dalam sistem air selama fase kematian
sehingga bahan ini cenderung dideteksi hanya
setelah fase kematian mikroorganisme [18].
Bagian daging ikan patin yang diindikasikan
off-flavoursditampilkan pada Gambar 12.
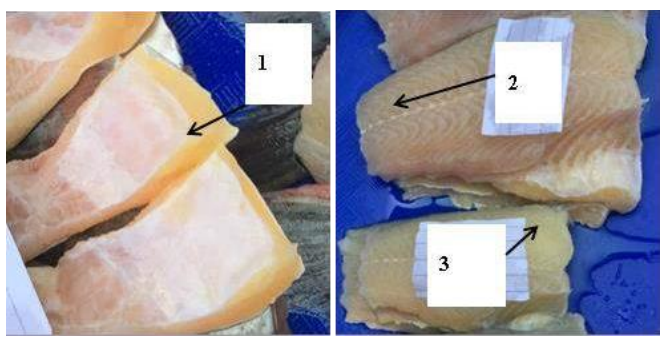

(A) Bagian daging ikan patin yang terindikasi muddy sebelum perlakuan.

Keterangan: Warna perut (1) agak kekuningan dan sedikit berbau tanah; warna ekor (2) agak kekuningan;dan punggung (3) agak kekuningan.
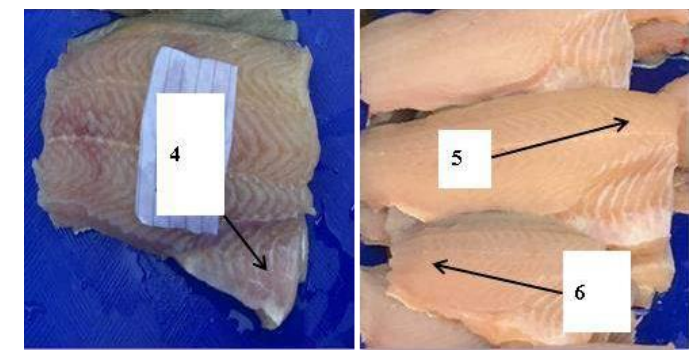

(B) Bagian daging ikan patin yang tidak terindikasi muddy sesudah perlakuan probiotik Bacillus spp. pada pakan.

Keterangan: Warna perut (4) kemerahan/putih pucat; warna punggung (5) agak kemerahan/putih pucat;dan warna ekor (6) kemerahan/putih pucat.
Gambar 12. Hasil pengecekan secara visual pada daging ikan patin yang mengindikasikan terdapat dan tidak terdapat muddy/off-flavours selama penelitian. Pengecekan tersebut dilakukan sebelum dan sesudah perlakuan probiotik Bacillus spp. pada pakan.

\section{Kesimpulan}

Penelitian tentang pengunaan probiotik Mina Pro (Bacillus spp.) pada pakan untuk menurunkan off-flavours diperoleh hasil yang menunjukan adanya perubahan/penurunan bau tanah pada perlakuan $10 \mathrm{ml} / \mathrm{Kg}$ pakan dan 20 $\mathrm{ml} / \mathrm{Kg}$ pakan jika dibandingkan dengan kontrol. Hasil organoleptik dari daging ikan patin pada perlakuan $20 \mathrm{ml} / \mathrm{Kg}$ pakan lebih rendah dibandingkan kontrol walaupun tidak berbeda dengan $10 \mathrm{ml} / \mathrm{Kg}$ yaitu 0,2 kategori sedikit muddy dibandingkan kontrol 0,3 atau kategori muddy sedang. Tetapi penurunan muddy tersebut dari masing-masing perlakuan sangat tipis (slight).

Probiotik Mina Pro (Bacillus spp.) baik digunakan sebagai alternatif untuk menurunkan bau tanah/lumpur. Pengaplikasian probiotik sebaiknya harus kontinyu dan seharusnya membutuhkan waktu yang cukup panjang, disarankan baik digunakan pada umur budidaya menjelang panen atau saat ikan berukuran konsumsi sehingga hasil yang diperoleh juga efektif. Tindakan tersebut untuk menjaga kualitas mutu daging ikan patin tetap dapat diterima pasar dengan harga yang sesuai tanpa teridentifikasi bau tanah atau offflavours.

\section{DAFTAR PUSTAKA}

[1] Abadi, A. F. 2009. Pengaruh pemberian suplemen pakan yang mengandung Bacillus spp. dalam pakan buatan terhadap laju pertumbuhan benih ikan Nila. Fakultas Perikanan dan Ilmu Kelautan. Universitas Padjadjaran, Bandung, $41 \mathrm{hlm}$.

[2] Adriyanto, S., Listyanto, N., dan Rahmawati, R. 2017. Pengaruh Pemberian Probiotik Dengan Dosis Yang Berbeda Terhadap Sintasan Dan 
Pertumbuhan Benih Patin Jambal. Pusat Riset Perikanan Budidaya. Jakarta.

[3][3] Azevedo EC, Rios EM, Fukushima K, dan GM Campos-Takaki. 1993. Bacitracin production by the new strain of Bacillus subtilis. Biochem Biotech Appl 42: 1-7.10.1007 / BF02788897.

[4] Bastiawan, D. A. Wahid., M. Alifudin, dan I. Agustiawan. 2001. Gambaran Darah Lele dumbo (Clarias spp.) yang Diinfeksi Cendawan Aphanomyces sp pada $\mathrm{pH}$ yang Berbeda. Jurnal penelitian Indonesia 7 (3): 44-47.

[5] Budianto, dan Heny S. 2017. Aktivitas Antagonis Bacillus Subtilis Terhadap Streptococcus Iniae Dan Pseudomonas Fluorescens. Jurnal Veteriner. Vol. 18 No. 3: 409-415

[6] Calik, P., Bilir, E., Çalik, G., dan Ozdamar, T. H. 2002. Influence of $\mathrm{pH}$ conditions on metabolic regulations in serine alkaline protease production by Bacillus licheniformis. Enzyme and Microbial Technology, 31 (5), 685-697. http://doi.org/10.1016/S01410229(02)00162-X

[7] Chiou CT. 1985. Partition Coefficients of Organic Compounds in Lipid-Water System and Correlations with Fish Bioconcentration Factors. Environmental Science and Technology 19, 57-62.

[8] Clous, D. dan R.C.W. Berkeley 1986. Genus Bacillus, In: Bergeys Manual of Systematic Bacteriology, vol 2: 11051139.

[9] Dellman, H. D dan E. M. Brown. 1989. Buku Teks Veteriner I. Terjemahan : R. Hartanto, Universitas Indonesia Press. Jakarta.

[10] Dickschat, JS, Bode, HB, Mahmud, T., Müller, R., dan Schulz, S. 2005. A novel type of geosmin biosynthesis in mycobacteria. Jouranl Organic Chemistry, 70, 5174-5182.

[11] Djaenuddin, N. dan Amran M. 2015. Karakteristik Bakteri Antagonis Bacillus Subtilis Dan Potensinya Sebagai Agens Pengendali Hayati
Penyakit Tanaman. Balai Penelitian dan Tanaman Selearia.

[12] Fuller, R. 1992. History and development of probiotics. In Fuller, $R$. (Ed.). Probiotics: The scientific Basis. Chapman and Hall, New York, p. 1-8.

[13] El Dakar, A.Y., S.M. Shalaby dan I.P. Saoud. 2007. Assessing the Use of a Dietary Probiotic/Prebiotics as an Enhancer of Spinefoot Rabbitfish Siganus rivulatus Survival and Growth. Aquaculture Nutrition. 13:407-412.

[14] Gerber, N. N. 1969. A volatile metabolite of actinomycetes: 2methylisoborneol. Journal ofAntibiotics, 22, 508-509.

[15] Giglio, S., Jiang, J., Saint, CP, Cane, DE, dan Monis, PT. 2008. Isolation and characterization of genes associated with geosmin production in cyanobacteria. Environmental Science and Technology, 42, 8027-8232. https://doi.org/10.1021/es801465w

[16] Gram, L. dan Huss, H.H., 1996. Microbiological spoilage of fish and fish products. International Journal of Food Microbiology, vol. 33, no. 1, pp. 121137.

[17] Grigorakis, K., Taylor, K.D.A. dan Alexis, M.N., 2003. Organoleptic and volatile aroma compounds comparison of wild and cultured gilthead sea bream (Sparus aurata): sensory differences and possible chemical basis. Aquaculture, vol. 225, no. 1-4, pp. 109-119.

[18] Guttman, L., dan van Rijn, J. 2008. Identify the conditions underlying the production of geosmin and 2methylisoborneol in the recirculation system. Aquaculture, 279, 85-91.

[19] Guttman, L., dan van Rijn, J. 2009. 2Methylisoborneol and geosmin extraction by organic sludge from recirculation aquaculture systems. Water Research, 43, 474-480.

[20] Hatmanti, A. 2000. Pengenalan Bacillus spp. Oseana, Volume XXV, Nomor 1, 31-41. 
[21] Hutchings E. 1998. Muddy Tasting Fish Cause and Recommendations. http://www.msstate.edu/dept/srac/

[22] Imam FG. 1977. Sintesis enzim ekstraseluler dalam genus Bacillus. 41:711-53.

[23] Irianto, A. 2003. Probiotik Akuakultur. Gadjah Mada University Press. Yogyakarta. 125.

[24] Izaguirre, G., Hwang, CJ, Krasner, SW, dan McGuire, MJ. 1982. Geosmin and 2methylisoborneol from cyanobacteria in 3 water supply systems. Applied Environmental Microbiology, 43, 708714.

[25] Jusadi, E. D., Gandara dan Mokoginta I. 2004. Pengaruh Penambahan Probiotik Bacillus spp. Pada Pakan Komersil Terhadap Konversi Pakan Dan Pertumbuhan Ikan Patin Pangasius Hypophthalmus. Jurnal Akuakultur

[26] Kamal, M. Basri., 2016, Pengaruh Receivable Turn Over Dan Debt To Asset Ratio (DAR) Terhadap Return On Asset (ROA) Pada Perusahaan Pertanian Yang Terdaftar Di Bursa

Efek Indonesia (BEI), Jurnal Ilmiah Manajemen dan Bisnis, Vol. 17 No. 02, 68-81.

[27] Kesarcodi-Watson, A., Kaspar, H., M. Lategan, J., dan Gibson, L. 2012. Probiotics in aquaculture: Needs, principles and mechanisms of action and screening process. Akuakultur, 274,114

[27] Killian, HS. 1977. Off-Flavor (Catfish). University of Arkansas Division of Agriculture.

[28] Kurniasih, T., Widanarni., Mulyasari., Melati I., Imran A. Z., Mariana L. A. 2013. Isolasi, Seleksi, Dan Identifikasi Bakteri Dari Saluran Pencernaan Ikan Lele Sebagai Kandidat Probiotik. Balai Penelitian Dan Pengembangan Budidaya Air Tawar Jakarta.

[29] Lagler KF, Bardach JE, RR Miller, Passino DRM. 1977. Ichthyology. John Willey and Sons. Inc. new YorkLondon. 506 hal.

[30] Latorre JD, Hernandez-Velasco X, Kallapura G. Menconi A. Pumford
NR,Morgan MJ. 2014. Evaluasi perkecambahan, distribusi, dan persistensi spora Bacillus

subtilis melalui saluran pencernaan. Poult Sci. 93:1793800.10.3382/ps.2013-03809.

[31] Liu XY, Wang Y, dan JI WX. 2011. Growth, feed utilization and body consumption of Asian catfsh Pangasius hypopthalamus feed at different dietary protein and lipid levels. Aquaculture Nutrition 11: 578-584.

[32] Madigans, M. T., J. M. Martinko, dan J. Parker. 1998. Biology of Microorganism, 8th editions. Baltimore: $110 \mathrm{pp}$.

[33] Mao, W., Pan, R., dan Freedman, D. 1992. High production of alkaline protease by Bacillus licheniformis in a fed-batch fermentation using a synthetic medium. Journal of Industrial Microbiology, $11 \quad$ (1), 1-6. http://doi.org/10.1007/BF01583724.

[34] Moran LA, Scrimgeour KG, Horton HR, Och RS \& Rawn JD. 1994. Biochemistry. Second edit. Prentice. Inc.

Upper Saddle River.

[35] Munro, A.L.S. 1978. The Aquatic Environtment. In Fish Pathology. Roberts, R.J. (ed). Bailliere Tindall, London.

[35] Ndome, C., Oriakpono, O. dan Agnes, O. 2010. Proximate composition and nutritional value of some commonly consumed fishes in Calabar. Journal of Tropical Freshwater Biology, vol. 19, pp. 11-18.

[36] Norris, J. R., R. C. W. Berkeley, N. A. Logan, dan A. G. O'donnell. 1981. The General Bacillus and Sporalactobacillus. In: The Prokaryotes, Vol 2: 1711-1742.

[37] Noviana, P., Subandiyono dan Pinandoyo. 2014. Pengaruh Pemberian Probiotik Dalam Pakan Buatan Terhadap Tingkat Konsumsi Pakan Dan Pertumbuhan Benih Ikan Nila (Oreochromis niloticus). Jurnal Manajemen dan Teknologi Akuakultur. Vol. 3. No. 4. Hal 183-190 
[38] Okpokwasili, GC, dan AM Alapiki. 1990. Bacterial fluids associated with Nigerian freshwater fish farming. $\mathrm{J}$. Aquacult. Trop. 5: 87-90.

[39] Parameswari, W., Dwi S. A. dan Muslim. 2013. Populasi Bakteri, Histologi, Kelangsungan Hidup Dan Pertumbuhan Benih Ikan Gabus

(Channa striata) Yang Dipelihara Dalam Media Dengan Penambahan Probiotik. Jurnal Akuakultur Rawa Indonesia. 1 (1): 76-89

[40] Parinduri, A., Usman S. dan Desrita. 2015. Effect Of Probiotic In Addition On Growth And Feed Conversion Ratio Of Catfish (P. hypopthalmus).

[41] Pelczar, M. J., Chan, E. C. S., 1988. Dasar-Dasar Mikrobiologi. Jakarta: Universitas Indonesia Press

[41] Pilmorat, P., Niwooti W., Chanagun C., Tomoaki I., dan Louis L. 2015. OffFlavor Characterization in HighNutrient-Load Tilapia Ponds in Northern Thailand. Turkish Journal of Fisheries and Aquatic Sciences 15: 273281.

[42] Pitrianingsih, C., Suminto., dan Sarjito. 2014. Pengaruh Bakteri Kandidat Probiotik Terhadap Perubahan Kandungan Nutrien $C, N, P$ dan $K$ Media Kultur Lele Dumbo (Clarias gariepinus). Journal of Aquaculture Management and Technology. 3 (4), 247-256.

[43] Phumee P, Hashim R, Aliyu-Paiko M, dan ShuChien AC. 2009. Effects of dietary protein and lipid content on growth performance and biological indices of iridescent shark Pangasius hypophthalmus, Sauvage 1878 fry. Aquaculture Research 40: 456-463.

[44] Ramos, MA, Weber, B., Gonçalves, JF, Santos, GA, Rema, P., dan Ozório, ROA 2013. Suplementasi probiotik diet memodulasi mikrobiota usus dan meningkatkan pertumbuhan ikan pelangi remaja (Oncorhynchus mykiss). Biokimia dan Fisiologi Komparatif, Bagian A, 166,302-307.

[45] Robertson, RF, Jauncey, K., Beveridge, MCM. dan Lawton. LA. 2005. The depuration rate and concentration of the geosmin sensory threshold responsible for the soil-musty stain on the rainbow trout,

Onchorhynchus mykiss.Akuakultur, 245, 89-99.

[46] Robert, R.T. 2001. Fish Pathology. Edisi III. W.B. Saunders. London Edinburg. Philadelphia, St. Louis,

Sydney, Toronto. $472 \mathrm{hlm}$.

[47] Roberts RJ, Ellis AE. 2012. The Pathophysiology and Systematic Pathology of Teleost. Di Dalam Roberts R.J. Fish Pathology. Ed ke-4. Chichester (UK): Wiley-Blackwell. hlm 22.

[48] Safratilofa. 2017. Histopatologi Hati dan Ginjal Ikan patin (Pangasionodon hypopthalmus) yang diinjeksi Bakteri Aeromonas hydrophila. Jurnal Akuakultur Sungai dan Danau, 2 (2): 8388.

[49] Septiarini, Harpeni E. dan Wardiyanto. 2012. Pengaruh Waktu Pemberian Probiotik Yang Berbeda Terhadap Respon Imun Non-Spesifik Ikan Mas (Cyprinus Carpio L.) Yang Diuji Tantang Dengan Bakteri Aeromonas Salmonicida. e-Jurnal Rekayasa dan Teknologi Budidaya Perairan Volume I No 1 Oktober 2012 ISSN: 2302-3600.

[50] Strzyzewska, E., J. Szarek., dan I. Babinska. 2016. Morphological Evaluation of The Gills as a Tool in The Diagnostics of Pathological Conditions in Fish and Pollution in The Aquatic Environment: a review. Veterinarni Medicina, 61 (3): 123-132.

[51] Sudarmadji, S. B. Haryono, dan Suhardi. 1984. Analisa Bahan Makanan dan Pertanian. Yogyakarta.

[52] Suryaningrum DT, Muljanah I, dan Tahapari E, 2010. Profil sensori dan nilai gizi beberapa jenis ikan patin dan hibrid nasutus. Jurnal Pascapanen dan Bioteknologi Kelautan dan Perikanan 5:153-164.

[53] Thammapat P, Raviyan P, dan Siriamorpon S. 2010. Proximate and fatty acids composition of muscles and viscera of Asian catfsh Pangasius 
bocourti. Food Chemistry 122: 223 227.

[54] Tucker, S. C. dan Martine V. D. P. 1999. Managing Off-Flavor Problems inPondRaised Catfish. Southern Regional Aquaculture Center. No. 192.

[55] Tucker, CS. 2000. The problem of offflavor in aquaculture. Reviews in Fisheries Science, 8, 45-88.

[56] Vreeland RH, Rosenzweig WD, Powers DW. 2000. Isolation of 250 Million Year-Old Halotolerant Bacteria from Primary Salt Crystals.407:897900.10.1038/35038060.

[57] Watson, K, A., Kaspar, H., Lategan, M.J., Gibson, L. 2008. Probiotics in aquaculture: The need, principles and mechanisms of action and screening processes. Aquaculture, Vol. 274. No.1, pp.1-14.

[58] Zakiyyah. I., Wasiq H. J. dan Muhammad F. 2016. Struktur Komunitas Plankton Perairan Payau di Kecamatan Wedung Kabupaten Demak. Vol. 18, No. 1, Hal. 89-96. ISSN:14108801

[59] Zhao, Y., Zhang, W., Xu, W., Mai, K., Zhang, Y., dan Liufu, Z. 2012. Potential influence of Bacillus subtilis T13 probiotics on growth, immunity and resistance to disease Vibrio splendidus infection in juvenile sea cucumbers Apostichopus japonicus. Imunologi Ikan dan Kerang, 32,750-755.

[60] [BSN] Badan Standarisasi Nasional. SNI-01-2354.4-2006. Uji Proksimat. Jakarta.

[61] [SNI]Standardisasi Nasional Indonesia. 2006. SNI 01-2346-2006. Petunjuk Pengujian Organoleptik Dan Atau Sensori. Badan Standardisasi Nasional.ICS 67.240.

[62] [NRC] National Research Council. 2011. Nutrient Requirements of Fish National Academy Press, Washington, DC:NRC
Lampiran 1. Prosedur pengujian bakteri air

1. Penanaman dan Penghitungan Bakteri TBC (Total Bacteria Count)

a) Ambil sample air menggunakan micropipet sebanyak $1 \mathrm{ml}$, masukan kedalam microtube kemudian di vortex/homogenkan.

b) Ambil 0,1 ml sample air Catatan:

- Tanpa pengenceran atau dengan pengenceran maksimal 10-3 (10-1, 10-2, 10-3) untuk TBC.

- Pengenceran menggunakan larutan $\mathrm{NaCl}$ fisiologis sebanyak $0,9 \mathrm{ml}$ yang sudah dimasukkan kedalam microtube.

- Pembuatan larutan pengenceran yaitu $\mathrm{NaCl}$ fisiologis sebanyak 8,5 gram dengan 1 liter aquades steril yang dipanaskan dengan hot plate dan di stir/aduk, tunggu hingga mendidih, kemudian di autoclave.

c) Inoculasi $0,1 \mathrm{ml}$ dari masing-masing pengenceran kedalam media TSA.

d) Speread atau ratakan menggunakan spreader glass.

e) Inkubasi selama 18-24 jam, dengan suhu $30^{\circ} \mathrm{C}$.

f) Hitung TVC (koloni kuning, hijau) dari masing-masing pengenceran. 
g) Jumlah bakteri $(\mathrm{cfu} / \mathrm{ml})=$ Jumlah koloni x Penyetaraan ke $1 \mathrm{ml} \mathrm{x}$ faktor pengenceran.

2. Penanaman dan Penghitungan Bakteri TAC (Total Aeromonas Count)

a) Ambil sample air menggunakan micropipet sebanyak $1 \mathrm{ml}$, masukan kedalam microtube kemudian di vortex/homogenkan.

b) Ambil 0,1 ml sample air.

c) Masukkan kedalam microtube yang berisi $\mathrm{NaCl}$ fisiologis $0,9 \mathrm{ml}$ (pengenceran 101 ), lalu vortekx.

d) Ambil sample $0,1 \mathrm{ml}$ dari pengenceran 1, masukkan kedalam microtube yang berisi $\mathrm{NaCl}$ fisiologis $0,9 \mathrm{ml}$ (pengenceran 102 ), lalu vortekx. e) Ambil 0,1 $\mathrm{ml}$ dari pengenceran 102 , lalu tuang pada cawan petridish.

f) Ratakan dengan menggunakan spreader glass.

g) Simpan dalam inkubator pada suhu $30^{\circ} \mathrm{C}$ selama 24 jam dalam posisi terbalik (tutup cawan petridish berada di bawah).

h) Jumlah bakteri $(\mathrm{cfu} / \mathrm{ml})=$ Jumlah koloni x Penyetaraan ke $1 \mathrm{ml} \mathrm{x}$ faktor pengenceran.

Lampiran 2. Prosedur pengamatan patologi ikan patin

Pengecekan meliputi organ lambung dan usus pada ikan patin secara visual, selanjutnya dipersentasekan sebagai berikut:
a) Kotoran lumpur =
$(\%)$
b) Plankton mati
$=$
$(\%)$

c) Sisa pakan =

d) Lain-lain =

Lampiran 3. Prosedur pengujian organoleptik muddy

Organoleptik (rasa) ditentukan oleh 3 bagian ikan (punggung, perut dan ekor) yang sering ditemukan adanya indikasi muddy pada daging ikan patin. Pengujian dilakukan oleh 6 orang panelis menggunakan skoring sebagai berikut:

\begin{tabular}{|c|c|c|}
\hline $\begin{array}{l}\text { Skala Rasa bau } \\
\text { lumpur/tanah } \\
\text { Sesifikasi sampel } \\
\text { ikan }\end{array}$ & Nilai & Kisaran muddy \\
\hline $\begin{array}{ll}\text { Sangat } & \text { Muddy } \\
\text { atau } & \text { Muddy } \\
\text { Tinggi } & \end{array}$ & 3 & 0,50 \\
\hline Muddy Sedang & 2 & 0,33 \\
\hline $\begin{array}{ll}\text { Sedikit } & \text { Muddy } \\
\text { atau } & \text { Kurang } \\
\text { Muddy } & \end{array}$ & 1 & 0,17 \\
\hline Normal & 0 & 0,00 \\
\hline
\end{tabular}

